\title{
Demand for Life Insurance and It's Determinants at Household Level: Evidence from Dire Dawa City
}

\author{
Hailay Aregawi Hagos (MSc.) ${ }^{1} \quad$ Estifanos Yilma Kebede (MBA) ${ }^{2}$ \\ Banbul Shewakena (Assistant Professor) ${ }^{2}$ \\ 1. Lecturer, Dire Dawa University, Department of Banking and finance \\ 2. Lecturer, Dire Dawa University, Department of Banking and finance \\ 2. Lecturer, Dire Dawa University, Department of Management
}

\begin{abstract}
The main aim of this study is to investigate the demand for life and its determining factors at household level in Dire Dawa city. For the sake of achieving this objective, primary sources of data were collected through structured questionnaire from a sample of 373 household respondents by applying a three stage multiple random sampling techniques. Moreover, data were also collected using face-to-face interview with insurance company managers and focus group discussion with some selected respondents. While descriptive narrations through concurrent triangulation strategy were applied to analyze the data collected using interview and focus group discussion, both descriptive tools and econometrics model (binary logit model) were employed to analyze the data collected using questionnaire. The result of the study revealed that the communities' demand for and awareness on life insurance is low. Besides, the study indicated that age, educational level, income level, occupation, number of dependent family size, knowledge, awareness, institutional factors, religion and perception were found statistically significant factors that determine the communities' willingness to purchase life insurance.
\end{abstract}

Keywords: Demand, life insurance, awareness, perception, willingness and insurance policy

DOI: $10.7176 /$ RJFA/10-17-06

Publication date:September $30^{\text {th }} 2019$

\section{Introduction}

Life insurance is part of insurance that pays monetary compensation upon the death of the insured covered in the policy. It is a contract between the insured and the insurer in which the insured agreed to pay premium periodically and the insurer agreed to provide financial protection for beneficiaries up on the policyholder's death (Madura, 2010). As part of the financial sector in general and insurance industry in particular, life insurance plays great role at an individual level and the economy as a whole. It contributes to the country's GDP, create employment opportunities, encourage saving, investment and development of capital markets (Francois, 1994; Curak et al, 2013). For instance, as it is cited in Thorsten and Ian (2002) during 1980s and 1990s it constitutes $11 \%$ of GDP for a sample of 13 countries which was increased to $28 \%$ of GDP in the period of 2000s. It also helps in reducing the financial and social burden to the community at large (Savvids, 2006). With regard to the individual role, life insurance provides financial security and planning, reduces psychological effect and develops saving habit for individuals so that it has taken increasing importance as a way for individuals and families to manage income risk (Thorsten \& Ian, 2002; Redzuan, 2014; Yilma, 2014).

In Ethiopia, the practice of offering life insurance began in the mid of $20^{\text {th }}$ century. Then after, its coverage and size has been increasing through the issuance of different laws and proclamations over time till the time when the derg regime come to power in 1974 and nationalized all insurance companies by merging them into a single company called Ethiopian Insurance Corporation. Following the change of government in 1991, the Federal Democratic Republic of Ethiopia (FDRE) issued a Proclamation No. 86/1994 and opened the insurance market to domestic private investors (Hailu, 2007). Currently, in Ethiopia, one state owned Insurance Corporation (Ethiopian Insurance Corporation) and sixteen private insurance Companies (Africa Insurance Company S.C, Awash Insurance Company S.C, Global Insurance Company S.C., Lion Insurance Company S.c, NIB Insurance Company, Nile Insurance Company S.C, Nyala Insurance Company S.C, United Insurance S.C, Abay Insurance Company, Berhan Insurance S.C., National Insurance Company of Ethiopia S.C., Oromia Insurance Company S.C., Ethio-Life and General Insurance S.C, Tsehay Insurance S.C., Lucy insurance S.C. and Buna insurance S.C.) are operating in the market (NBE, 2015).

However, regardless of the sectors role on country's economy and its expansion, insurance market in general and life insurance market in particular is small underdeveloped. For instance, the premiums of the insurance industry were ETB 5.6 Billion in the year 2014/2015 which represents only $0.81 \%$ of GDP. Life insurance premiums constituted only U.S. Birr 314 million or 5.7\% of the total premiums in 2014/2015, while general insurance premiums totaled Birr 5.2 Billion or $94.3 \%$ of the total premiums (NBE, 2015). This is lower even compared to some other African countries' insurance penetration rate like South Africa (15.3\%), Namibia (8.1\%), Botswana (3.9\%), Morocco (3.4\%), Kenya (2.5\%), Tunisia (2.0\%), Angola (1.4\%) and Egypt (0.9\%) 
(Mezgebe, 2015). Besides, in Ethiopia, out of the seventeen insurance companies, eight of them does not provide life insurance coverage rather they only provide general insurance (NBE, 2015). In their study, Hailu (2007) and Roman (2011) also reported that the Ethiopian insurance industry in general and the life insurance in particular is underdeveloped. Thus, it calls academicians and researchers to conduct studies in the area and indicate possible solutions for the problem.

In relation to this, some studies have been conducted and forward conclusions. A study made by Stephanie (2005); Luciano, et al. (2015) revealed that economic, legal/political, age and social factors are the factors affecting the insurance demand. According to the Marijana, et al. (2013); Thorsten and Ian, (2002) age, education, young dependency ratio, life expectancy, and size of social security are statistically significant factors affecting the life insurance demand. Researchers (Curak et at,2013; Mhere, 2013; Ondruska et at, 2016; Mulenga et al, 2017; Dash, 2018) found that age of respondents have significant factor on determining the demand for life insurance. Other studies (Mulenga et al, 2017; Lenten \& Rulli, 2006; Shahnaz \& Margaret, 2013; Redzuan, 2014; Mapharing et al, 2015; Akhter \& Ullah, 2017) conducted study on the area and reported different findings. In Ethiopia, a few studies (Roman, 2011; Aderaw, 2013; Simon, 2016) have conducted to identify the factors affecting the demand of life insurance. Based on the study made by Aderaw (2013) per capita income, life expectancy, real interest rate and inflation are the significant factors affecting life insurance demand. Simon (2016) also reported that inflation, price of life insurance, age and dependency ratio is the factors affecting the demand for life insurance.

Most of the studies undertaken in this area are in foreign countries especially in developed countries so that their findings may not be applicable to other countries, like Ethiopia due to differences in cultural, economic and legal environments. Besides, as it can be seen from the review of previous empirical studies, their findings are inconsistent. In addition, the few studies conducted in Ethiopia were focused on the investigation of factors affecting the demand for life insurance through gathering secondary data on a country level. To this effect, they focused on few variables such as education, dependency ratio, per capita income, life expectancy, interest rate, inflation rate and other macroeconomic variables which can be obtained via secondary data at country level. However, in this study other variables such as gender, age, marital status, religion, awareness and perception were incorporated by collected them at household level using primary sources including questionnaire, interview and focus group discussion. Therefore, to fill the specified gap the researchers were motivated to conduct a study mainly aimed at investigating the demand for life and its determinant in case of Dire Dawa city. More specifically, the study was aimed to achieve the following objectives:

1. To describe the demand situation of life insurance in Dire Dawa city.

2. To analyze the communities' awareness on life insurance in Dire Dawa city.

3. To analyze the communities' perception towards life insurance in Dire Dawa city.

4. To identify the factors determining the demand for life insurance in Dire Dawa city.

\section{Review of Related Literature}

\subsection{Concept of Life Insurance}

Scholars and writers have given various definitions for insurance in general and life insurance in particular from different perspectives such as, economic, social, business, legal, etc. According to Rejda (2003) insurance is the tool of transferring accidental losses from the insured to insurer in which the insured agreed to pay premium periodically and the insurer to provide compensation and other benefits when a loss occurred. Generally insurance is categorized in to two basic categories: life insurance and general insurance. The first category includes health, life, disability, Medicare, Medicaid and so on, while the second category includes motor, homeowner's, liability, fire and other types of insurance (Hailu, 2007; OCI, 2013).

Life insurance on the other hand, is a contract between the insured and the insurer in which the insured agreed to pay premium periodically and the insurer agreed to provide financial protection when a loss such as death, disability and damage occurred during the term of the policy (Rejda, 2003; Hailu, 2007; NBE, 2015). It is a form of insurance that pays monetary proceeds upon the death of the insured covered in the policy. According to Madura (2010) life insurance is an agreement between the insurance company and the policyholder for which the former compensate the beneficiary of a policy upon the policyholder's death, whereas the later party pays the fixed premium amount periodically. Life insurers pay death benefits including funeral expenses, uninsured medical bills, estate taxes, and other expenses to designated beneficiaries when the insured dies (Rejda, 2003).

According to Jones and Silver (2011) life insurance is part of insurance that provide different life insurance coverage under various policies. These policies are grouped in to three basic categories: term life insurance policy, whole life insurance policy and endowment life insurance policy. The term life insurance is life insurance policy that provides death benefit to the beneficiary if the insured dies within the specified time period stated in the policy. In other words, it matures for payment only on the death of the insured within the term period, but if he/she survivals the policy will expire and nothing is payable to the insured. Whole life insurance is the second group of life insurance plicy that provides lifetime insurance coverage at a level premium payment, limited 
premium payment or single premium payment whole life policy. Endowment life insurance, on the other hand, is a modified form of the above two policies in which it provides a policy benefit payable on a stated date regardless of the insurd's death. Under each of the three policies there various sub policies issued for clients based on their respective interest (Rejda, 2003; Jones and Silver, 2011).

\subsection{Theoretical Review}

Yaari (1965) was the first person who established a theoretical model for the life insurance demand. He developed the life cycle utility model of a consumer together with the optimal consumption and saving plans of a consumer in reference to the models of utility functions. Finally, his result shows that individuals increase their expected lifetime utility by buying life insurance which is the function of wealth, expected income, interest rates, the cost of life insurance policies and estimated discount rate. Following Yaari (1965), some authors also forwarded different models by extending his model. Fisher (1973) incorporated the demand for term life insurance into his model that explains the demand for life insurance in the form of limited term. Lewis (1989) also adds the purpose of purchasing life insurance to Yaari's model. Accordingly, he suggested that the goal of purchasing life insurance is securing the survival of the dependents due to the death of breadwinner. Pissarides (1980) prove that life insurance was theoretically capable of absorbing all fluctuations in lifetime income.

Furthermore, Mossin (1968); Karni and Zilcha (1985) developed life insurance model in relation to individuals' risk averse perception and demand for life insurance. Accordingly, they reported that demand for life insurance varies inversely with the amount of wealth an individual possesses. By examining the implication of expected utility choice, Fortune (1973) also reported that demand for life insurance depends on income, wealth and the rate of discount. Other authors (Hammond, Houston \& Melander, 1967; Berekson, 1972; Headen \& Lee, 1974) revealed that income, age, net worth, education, marital status, family size and financial conditions positively affect the demand for life insurance. To sum up, from the above theoretical analysis and results, different economical, social and demographic variables that can determine the demand for life insurance were forwarded by scholars over time. Besides, in the next section, the researchers also review some empirical studies on the area and identify the variables found that can determine the demand for life insurance.

\subsection{Empirical Review}

To investigate the driving force of life insurance demand and family consumption, Redzuan (2014) made a study via gathering data using annual time series covering the period from 1970 to 2008. The results of analysis suggest that the level of income, number of dependents and level of education are positively influenced life insurance demand and family consumption in Malaysia, while social security, rate of inflation and interest rate were found to have a negative impact. In the same country, Idham et al (2014) have conducted a study with the main objective of investigating the factors affecting the demand for life insurance using data collected from questionnaire. In doing so, customer perception, income, price of insurance and the rate of interest were the significant variables affecting the demand for life insurance in the study area. With a similar research approach, Akhter and Ullah (2017) made a study and concluded that income, financial sector, dependency ratio, inflation, urbanization and education were the significant factors affecting the life insurance demand.

Based on survey data collected by the Bank of Italy in 2012, Luciano, Outreville and Rossi (2015) made a study with the aim of estimating the influence of microeconomic determinants for men and women on life insurance purchase decisions. The result of the study indicates that women are less likely to pay for an insurance contract than men. Besides, income, family structure and employment status and financial proximity are the factors affecting the decision to purchase life insurance. Similarly, to analyze the social and demographic determinants of life insurance consumption in Croatia, a study was conducted by Curak et al. (2013). In the study, the required data were collected from primary sources through questionnaire. Accordingly, age, education and employment impact are the factors affecting of life insurance demand of household in Croatia. With the same research approach followed by Curak et al. (2013), Dash (2018) made a study on the same area and reported that age, insurance companies' policy pricing, income level, occupation and education level of respondents were statistically significant variables in determining the decision of respondents to purchase life insurance policy.

Novovic et al (2017) also made a study on the area with the aim of identifying the significant economic factors that affect life insurance demand in Western Balkan countries based on the panel data gathered for the period between 2005 and 2015. Finally, the regression results of the study showed that GDP and wages have a significant and positive impact on demand for life insurance, while the impact of unemployment rate and interest rate is negative on the demand of life insurance. On the other hand, based on the data collected using questionnaire, Shahnaz and Margaret (2013) reported that demographic variables and saving motives were significantly related to life insurance demand. In the area, Mapharing et al (2015) was also reported that education, income, inflation, social security, interest rates, dependency ratio, financial development and life expectancy have long term relationship with life insurance. Ondruska et al (2016) carried out a study that examines the personal, demographic and economic factors determine the consumption of life insurance policy 
based on the data collected from questionnaire. Accordingly, age, education, savings and employment status are the most most significant factors that determine the life insurance consumption.

Aderaw (2013) on his article "determinants of life insurance in Ethiopia" examined the determinants of life insurance by a time series data for the period 1991-2010. He identified that life insurance is determined by per capita income, life expectancy, real interest rate and inflation. Similarly, Simon (2016) have conducted a study that aimed at examining the macro level variables influencing life insurance policy purchasing demand in Ethiopia. To acheive the objective secondary data were gathered for a period of 15 years from 2000/2001 to 2014/2015 on different dependent and independent variables. Hence, based on the regression analysis, he reported that inflation, price of life insurance, age and dependency ratio have statistically negative impact on the purchasing of life insurance policy as well as literacy rate, per capita income, life expectancy and financial development have positive statistically significant influence on life insurance demand in Ethiopia.

\subsection{Conceptual Framework of the Study}

In line to the theretical and emprical reviews discussed above, the conceptual framework of the study is given below:

Figure 1: Conceptual Framework of the Study

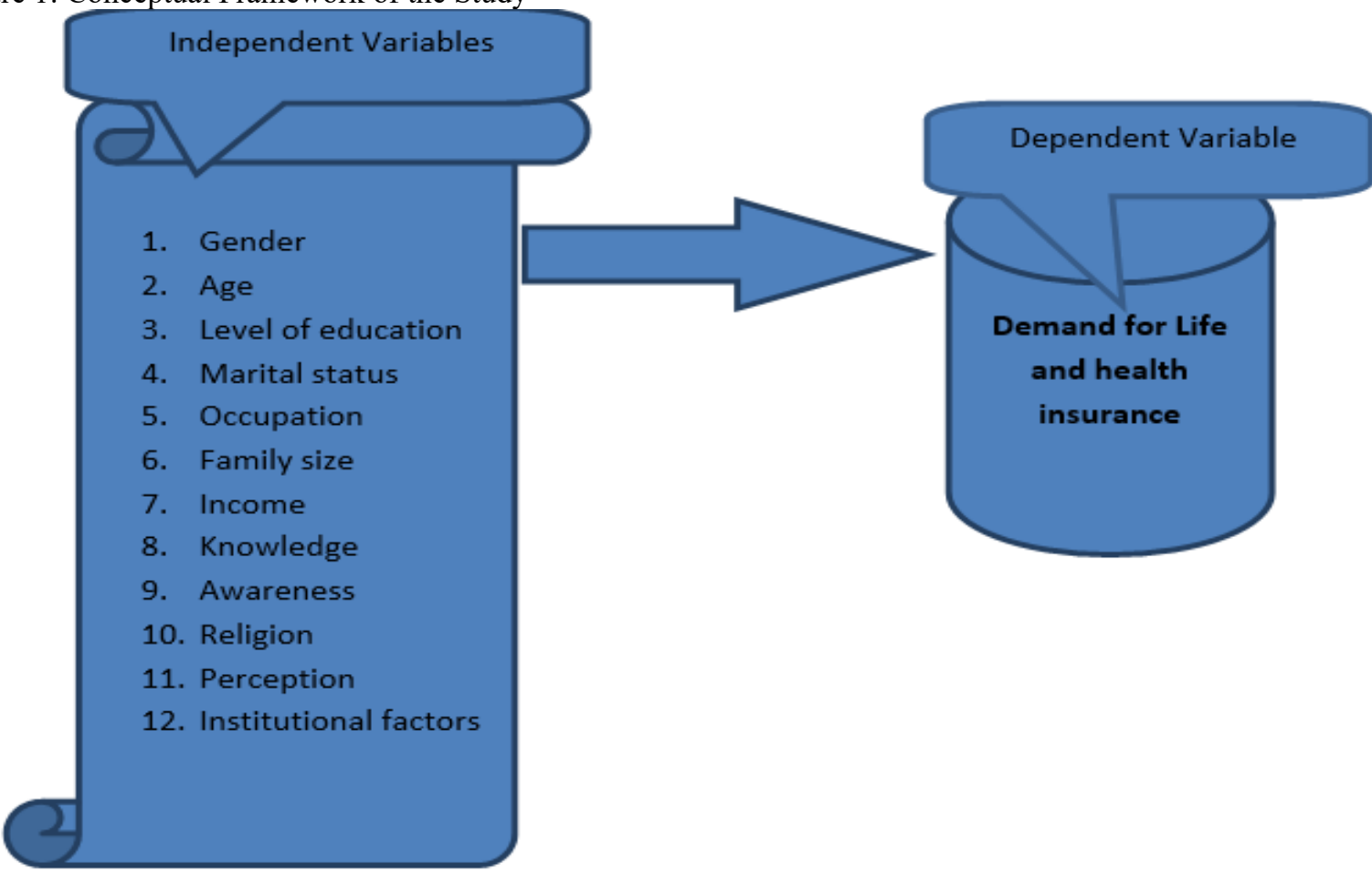

Source: Researchers' design developed by reviewing different literature

\section{RESEARCH METHODOLOGY}

In the study the existing communities' demand situation for, awareness and perception towards life insurance were described using descriptive analysis techniques. Besides, the effect of the explanatory variables on the demand for life insurance was also explained using inferential analysis tool. In all cases, both qualitative and quantitative data were collected on a cross-sectional research basis. Primary data were collected from primary sources by employing questionnaire, interview, and focus group discussion. In the study area (Dire Dawa city), there are nine Kebels which are again organized in to different Ketenas. In order to include respondents from different socia-demographic and economic characteristics, in the study three stage multiple random sampling technique was applied. That means at first stage five kebeles were randomly selected and then at the second stage one Ketena from each selected kebele were selected. Finally, sample of households from each Ketena were selected by applying a simple random sampling technique. With regard to the sample size, samples of 398 household respondents were selected by applying a simplified scientific formula provided by Yemane (1997) i.e. $n=\frac{N}{1+N(e) 2}$.

The collected data were analyzed using both descriptive and econometrics analysis tools. While the data collected through questionnaire on each objective were analyzed by applying the descriptive statistical tools, 
descriptive narration through concurrent triangulation strategy was applied to analyze the data collected through interview questions and focus group discussions. Besides, an econometric model (binary logit model) was employed particularly to test the relationship between the dependent and independent variables and to draw conclusions. Stata, version 11.2 software was used to run the result of the statistical result and the model. In this study the demand for life insurance is dependent variable which is measured by the respondents willingness to purchase life insurance policy. That means respondents who have already purchased the life insurance policy or respondents who are ready/interested to purchase the policy were cansidered as willing and takes a value one, while respondents neither purchased life insurance policy nor uninterested to purchase the policy were cansidered as unwilling and takes a value zero. Accordingly, the dependent variable of this study was a dummy variable which contains two categorical response: willing and unwilling response. The explanatory variables of the study, on the other hand, includes gender, age, educational level, marital status, occupation, income level, number of dependent family size, knowledge on insurance, awareness, religion, perception of respondents and institutional factors. In regressing the model, the variables measured using five point likert scale are reduced to two categories: "agree and disagree". That is the average response of respondents less than 2.5 were categorized as "disagree" and the average response of respondents greater than or equal to 2.5 were categorized as "agree" based on the rule of half. The derived equation of the model in this study which is the function of dependent variable to various explanatory variables is given as:

LWill $=\beta_{0}+\beta_{1 \mathrm{GEN}}+\beta_{2 \mathrm{AG}}+\beta_{3 \mathrm{Ed}}+\beta_{4 \mathrm{MRS}}+\beta_{5 \mathrm{OC}}+\beta_{6 \mathrm{FS}}+\beta_{7 \mathrm{IC}}+\beta_{8 \mathrm{KN}}+\beta_{9 \mathrm{AW}}+\beta_{10 \mathrm{RL}}+\beta_{11 \mathrm{PR}}+\beta_{12 \mathrm{IF}}+\varepsilon \mathbf{i}$

Where, $\quad$ LWill $=$ the willingness to purchase life insurance

$\beta_{0}=$ Constant (intercept)

$\boldsymbol{E}_{i=\text { Error term }}$

$\beta_{1}, \beta_{2} \ldots \beta_{9}=$ slope coefficients of independent variables (the unknown parameters that reflecting the impact of change in independent variables).

GEN $=$ gender

$\mathbf{A G}=$ age

$\mathbf{E D}=$ education

MRS = marital status

OC $=$ occupation

FMS = family size

IC: income

KN: knowledge

$\mathbf{A W}=$ awareness

$\mathbf{R L}=$ Religion

$\mathbf{P C}=$ perception

IF: institutional factor

To test the reliability of the data collected through questionnaire in the form of scale, in the study, a cronbach's alpha test were conducted. Besides, test of data fitness, specification bias, multicolliniarity, and heteroscedasticity problem were made before interpreting the obtained result from the model.

\section{DATA ANALYSIS AND DISCUSSION}

\subsection{Demand Situation of Life Insurance in the Study Area}

As it is specified in the objective part of the study, describing the demand situation of life insurance in the study area is the first objective. To achieve this objective, primary data were collected from participants of the study via questionnaire, interview and focus group discussions. In the questionnaire, respondents were requested to state their opinion on the necessity of life insurance compared to other traditional methods like Idir, and their willingness to purchase life insurance as well as the reason behind for not willing (if any). Each of the questions was raised for the respondents separately for life insurance. The summary of their response for each of the items is given in the below table. 
Table 1: Respondents response on life insurance demand

\begin{tabular}{|c|c|c|c|c|}
\hline \multirow[t]{2}{*}{ No. } & \multirow[t]{2}{*}{ Variable/Item } & \multirow[t]{2}{*}{ Category } & \multicolumn{2}{|c|}{ Life insurance } \\
\hline & & & Number & Percent \\
\hline \multirow[t]{5}{*}{1} & \multirow{5}{*}{$\begin{array}{l}\text { Life insurance comparing to other } \\
\text { traditional methods }\end{array}$} & Very good & 99 & 26.5 \\
\hline & & Good & 114 & 30.5 \\
\hline & & Not necessary & 96 & 26 \\
\hline & & I don't & 64 & 17 \\
\hline & & Total & 373 & 100 \\
\hline \multirow[t]{3}{*}{2} & \multirow{3}{*}{$\begin{array}{l}\text { Life insurance demand (Willingness to } \\
\text { buy) }\end{array}$} & Willing & 132 & 35 \\
\hline & & Not willing & 241 & 65 \\
\hline & & Total & 373 & 100 \\
\hline \multirow[t]{5}{*}{3} & \multirow[t]{5}{*}{ Reasons for not buying } & no enough capital & 86 & 36 \\
\hline & & Not necessary & 56 & 23 \\
\hline & & I have Idir & 47 & 19 \\
\hline & & I don't at all & 52 & 22 \\
\hline & & Total & 241 & 100 \\
\hline
\end{tabular}

Source: Own survey (2018)

As it is depicted in table 1, item one, respondents were asked that "How do you see life insurance comparing to other traditional methods (Idir or Equb) as a means of reducing risk of death problem"? In response, 26.5, 30.5, 26 and 17 percent of the respondents were repaid very good, good, not necessary and I don't for life insurance part respectively. This shows that most (57 percent) of them were replayed positive response as very good or good, while the remaining (43 percent) of them were replayed negative response as not necessary or I don't. In the same table item 2, respondents were also asked about their willingness for purchasing life insurance policy. In response, most (65 percent) of the surveyed respondents did not willing to purchase life insurance policy, whereas the remaining 35 percent were willing to purchase life insurance policy. Besides, for those who were not willing to purchase life insurance, they were also required to state the reason why they didn't demanded. Accordingly, 36 percent, 23 percent, 19 percent and 22 percent of the respondents were said I have no enough capital, it is not necessary, I have Idir and I don't at all respectively for life insurance part. From this we can understand that even though there are many people agree with necessity of life insurance policy, their willingness to purchase these policies was low with different reasons such as less capita, unnecessarily, having Idir and so on.

With regard to interview method and focus group discussion, a face to face interview with the life insurance managers of five insurance companies and discussion with some selected communities from each kebele were made. The result of the interview indicated that the communities demand for life insurance is low. In their respective insurance company, the amount of premium collected from life insurance is too low. Even the smaller amount of premium is obtained from organizations that they paid for their employees as an allowance for life insurance. Otherwise, obtaining a voluntary person who motivates to purchase life insurance for his/her life is a very rare. According to the response obtained from focus group discussions, the status of life insurance demand is again found low. The participants of the discussion were not willing to purchase life insurance totally even once the interviewer explained the nature and purpose of purchasing life and health insurance. They consider Idir is enough for them. They also assume that life insurance is costly and contradicts it with their culture and religion. This implies that the demand situation of life insurance is generally low.

\subsection{Communities' Knowledge and Awareness towards Life Insurance}

Before investigating the awareness of communities' about life insurance particularly, in this study knowledge of communities about insurance in general was identified through providing alternative definitions that explain insurance and that not related to it. In doing so, a choice question that includes one sentence/alternative that correctly explain insurance and other three sentence/alternatives that incorrectly explain insurance were provided to be chosen by respondents. The list of the alternatives and the response of respondents are summarized in the below table: 
Table 2: Knowledge of respondents towards insurance

\begin{tabular}{|l|l|l|l|}
\hline No. & \multicolumn{1}{|c|}{ Alternatives } & \multicolumn{2}{c|}{ Response } \\
\cline { 3 - 4 } & & Number & Percent \\
\hline 1 & Insurance is a company that provides banking services & 64 & 17 \\
\hline 2 & Insurance is a manufacturing company that manufactures products & 33 & 9 \\
\hline 3 & Insurance is a company that provides claim for damaged peoples/products & 146 & 39 \\
\hline 4 & Insurance is a company to collect money from the communities & 131 & 35 \\
\hline Total & & 373 & 100 \\
\hline
\end{tabular}

Source: Own survey (2018)

As it is shown in the above table, 17, 9, 39 and 35 percent of the surveyed respondents were answered the first, second, third and fourth sentences/alternatives respectively. This indicates that most (61 percent) of the surveyed respondents replied the incorrect sentences, while the remaining 39 percent of respondents answered the correct sentence. Thus, although some respondents have knowledge on insurance, most of the surveyed respondents did not know what insurance is. More specifically, respondents were also required to state their level of awareness towards life insurance on a five point likert scale for the given measurements/variables. To evaluate their awareness level, respondents were required to forward their opinion in relation four items about insurance. Accordingly, the list of the variables and the respondents' response is summarized in the below table:

Table 3: Communities Awareness towards Life Insurance

\begin{tabular}{|c|c|c|c|c|}
\hline \multirow[t]{2}{*}{ No. } & \multirow[t]{2}{*}{ Variable } & \multirow[t]{2}{*}{ Category } & \multicolumn{2}{|c|}{ Life insurance } \\
\hline & & & Number & Percent \\
\hline \multirow[t]{6}{*}{1} & \multirow{6}{*}{$\begin{array}{l}\text { I know how insurance can be } \\
\text { purchased }\end{array}$} & Strongly agree & 59 & 16 \\
\hline & & Agree & 42 & 11 \\
\hline & & Neutral & 62 & 17 \\
\hline & & Disagree & 106 & 29 \\
\hline & & Strongly disagree & 100 & 27 \\
\hline & & Total & 373 & 100 \\
\hline \multirow[t]{6}{*}{2} & \multirow{6}{*}{$\begin{array}{l}\text { I know the services provided } \\
\text { under insurance }\end{array}$} & Strongly agree & 56 & 16 \\
\hline & & Agree & 50 & 13 \\
\hline & & Neutral & 29 & 8 \\
\hline & & Disagree & 133 & 36 \\
\hline & & Strongly disagree & 102 & 27 \\
\hline & & Total & 373 & 100 \\
\hline \multirow[t]{6}{*}{3} & \multirow{6}{*}{$\begin{array}{l}\text { I know the advantages of } \\
\text { insurance }\end{array}$} & Strongly agree & 64 & 17 \\
\hline & & Agree & 37 & 10 \\
\hline & & Neutral & 39 & 11 \\
\hline & & Disagree & 113 & 31 \\
\hline & & Strongly disagree & 116 & 31 \\
\hline & & Total & 373 & 100 \\
\hline \multirow[t]{6}{*}{4} & \multirow{6}{*}{$\begin{array}{l}\text { I know how insurance service } \\
\text { can be used }\end{array}$} & Strongly agree & 61 & 17 \\
\hline & & Agree & 56 & 15 \\
\hline & & Neutral & 12 & 3 \\
\hline & & Disagree & 92 & 25 \\
\hline & & Strongly disagree & 146 & 40 \\
\hline & & Total & 373 & 100 \\
\hline
\end{tabular}

Source: Own survey (2018)

As it is stated in the above table (table 3), four variables (how to purchase, services provided, advantage and usage of insurance) were used to identify the respondents' awareness towards life insurance which are measured based on five point likert scale. With regard to the first variable (I know how insurance can be purchased), most (56 percent) of the respondents were disagreed with the statement (i.e. 29 percent says disagree and 27 percent of them said strongly disagree). The remaining 17 percent, 11 percent and 16 percents of respondents were said neutral, agree and strongly agree respectively. Similarly, the response of respondents for the other variables respondents was also similar with the exception of certain numerical differences. That is for both variables, most respondents disagreed and few respondents agreed with the statement (see table 3). From this it is possible to understand that most of the surveyed respondents have low awareness of life insurance in particular and on insurance in general.

Furthermore, focus group discussions with some selected respondents as well as face to face interview with managers of the selected insurance company were made to evaluate the knowledge and awareness of the 
communities to insurance in general and for life insurance in particular. Accordingly, the response obtained from both approaches indicated that the knowledge and awareness level of the communities about life insurance is very low. The societies in general do not want to buy life insurance. Some religions prohibit their follower for not purchasing life insurance. It was tried to collaboratively work with Idir with service of covering funeral cost coverage with a cheap price but there was resistance from higher official of the Idir because of awareness and knowledge gap. From the discussion the researchers understand that the reason for low level of knowledge and awareness for life insurance is the low level of emphasis given by the top authority of life insurer take the lion share.

\subsection{Communities Perception towards Life Insurance}

The level of communities' perception on the usefulness and thereby to purchase life insurance was also the other objective of the study. In relation to this objective, data were collected from respondents using questionnaire, focus group discussion and interview. With the first method (questionnaire), respondents were required to state their level of perception on purchasing both life and health insurance on five point likert scale. To this effect, eight perception variables were raised to evaluate the respondents' perception towards life insurance. The summary of the response of the respondents for each of the variables are given in the below table.

Table 4: Communities Perception towards Life Insurance

\begin{tabular}{|c|c|c|c|c|}
\hline \multirow[t]{2}{*}{ No. } & \multirow[t]{2}{*}{ Variable } & \multirow[t]{2}{*}{ Category } & \multicolumn{2}{|c|}{ Life insurance } \\
\hline & & & Number & Percent \\
\hline \multirow[t]{6}{*}{1} & \multirow{6}{*}{$\begin{array}{l}\text { I believe It is for the rich } \\
\text { people }\end{array}$} & Strongly agree & 81 & 22 \\
\hline & & Agree & 160 & 43 \\
\hline & & Neutral & 34 & 9 \\
\hline & & Disagree & 44 & 12 \\
\hline & & Strongly disagree & 54 & 14 \\
\hline & & Total & 373 & 100 \\
\hline \multirow[t]{6}{*}{2} & \multirow{6}{*}{$\begin{array}{l}\text { I believe For me Idir is enough } \\
\text { for reducing my risk of life }\end{array}$} & Strongly agree & 97 & 26 \\
\hline & & Agree & 120 & 32 \\
\hline & & Neutral & 43 & 12 \\
\hline & & Disagree & 38 & 10 \\
\hline & & Strongly disagree & 75 & 20 \\
\hline & & Total & 373 & 100 \\
\hline \multirow[t]{6}{*}{3} & \multirow{6}{*}{$\begin{array}{l}\text { I believe It contradict with the } \\
\text { principle of my religion }\end{array}$} & Strongly agree & 60 & 16 \\
\hline & & Agree & 101 & 27 \\
\hline & & Neutral & 74 & 20 \\
\hline & & Disagree & 49 & 13 \\
\hline & & Strongly disagree & 89 & 24 \\
\hline & & Total & 373 & 100 \\
\hline \multirow[t]{6}{*}{4} & \multirow{6}{*}{$\begin{array}{l}\text { I believe It contradict with my } \\
\text { culture }\end{array}$} & Strongly agree & 76 & 20 \\
\hline & & Agree & 106 & 28 \\
\hline & & Neutral & 73 & 20 \\
\hline & & Disagree & 37 & 10 \\
\hline & & Strongly disagree & 81 & 22 \\
\hline & & Total & 373 & 100 \\
\hline
\end{tabular}




\begin{tabular}{|c|c|c|c|c|}
\hline \multirow[t]{2}{*}{ No. } & \multirow[t]{2}{*}{ Variable } & \multirow[t]{2}{*}{ Category } & \multicolumn{2}{|c|}{ Life insurance } \\
\hline & & & Number & Percent \\
\hline \multirow[t]{6}{*}{5} & \multirow[t]{6}{*}{ I believe Not affordable } & Strongly agree & 89 & 24 \\
\hline & & Agree & 175 & 47 \\
\hline & & Neutral & 35 & 9 \\
\hline & & Disagree & 39 & 11 \\
\hline & & Strongly disagree & 35 & 9 \\
\hline & & Total & 373 & 100 \\
\hline \multirow[t]{6}{*}{6} & \multirow[t]{6}{*}{ I believe It is costly } & Strongly agree & 104 & 28 \\
\hline & & Agree & 172 & 46 \\
\hline & & Neutral & 27 & 7 \\
\hline & & Disagree & 37 & 10 \\
\hline & & Strongly disagree & 33 & 9 \\
\hline & & Total & 373 & 100 \\
\hline \multirow[t]{6}{*}{7} & \multirow{6}{*}{$\begin{array}{l}\text { I believe It does not have } \\
\text { psychological support }\end{array}$} & Strongly agree & 74 & 20 \\
\hline & & Agree & 158 & 42 \\
\hline & & Neutral & 67 & 18 \\
\hline & & Disagree & 28 & 8 \\
\hline & & Strongly disagree & 46 & 12 \\
\hline & & Total & 373 & 100 \\
\hline \multirow[t]{6}{*}{8} & \multirow{6}{*}{$\begin{array}{l}\text { I believe life insurance does } \\
\text { not provide better protection to } \\
\text { my dependent }\end{array}$} & Strongly agree & 69 & 19 \\
\hline & & Agree & 143 & 38 \\
\hline & & Neutral & 55 & 15 \\
\hline & & Disagree & 57 & 15 \\
\hline & & Strongly disagree & 49 & 13 \\
\hline & & Total & 373 & 100 \\
\hline
\end{tabular}

Source: Own survey (2018)

As it is shown in the above table (table 4), item 1, most (65 percent) of the respondents agreed (i.e. 22 percent of them said strongly agree and 43 percent of them said agree) with the statement, while the remaining 9 percent and 26 percent of them were responded neutral and disagreed (12 percent said disagree and 14 percent said strongly disagree) respectively. Similarly, on the remaining item (item 2, 3, 4, 5, 6, 7 and 8) of the same table, most of the respondents were responded "agree" for each statement and the remaining respondents replay neutral and disagree (see table 4). This indicates that most of the surveyed respondents perceived life insurance is for rich peoples; idir substitutes life insurance policy; life insurance contradicts with religion and culture; it is expensive; it could not cover psychological effect; and it's coverage is not financially sufficient. In addition to the questionnaire approach, focus group discussion and interview were also made with respondents so as to evaluate the communities' perception towards life and health insurance. The response obtained from respondents using both approaches indicated that the communities' perception towards life insurance as contradiction with their culture and religion is low. However, most of them perceived life insurance especially it as for rich peoples, and it is costly. The community also perceives as the informal association such as indir and equb can better provide the service than insurance. 


\subsection{Factors Affecting the Demand for Life Insurance}

\subsubsection{Socio-Demographic and Economic Factors}

Here different socio-demographic and economic factors including gender, age, educational level, marital status, occupation, number of dependent family size, and income level of respondents were incorporated and data on each of them were collected from each respondent. Table 5 summaries the result of the response obtained in relation to each of the variables.

Table 5: Demand of life insurance and socio-demographic and income factors

\begin{tabular}{|c|c|c|c|c|c|c|c|}
\hline \multirow[t]{3}{*}{ No. } & \multirow[t]{3}{*}{ Variable } & \multirow[t]{3}{*}{ Category } & \multicolumn{5}{|c|}{ Demand of life insurance } \\
\hline & & & \multicolumn{2}{|c|}{ Willing } & \multicolumn{2}{|c|}{ Not Willing } & \multirow{2}{*}{$\begin{array}{l}\text { Total } \\
\text { No. } \\
\end{array}$} \\
\hline & & & No. & $\%$ & No. & $\%$ & \\
\hline \multirow[t]{2}{*}{1} & \multirow{2}{*}{ Gender } & Male & 77 & 38 & 128 & 62 & 205 \\
\hline & & Female & 55 & 33 & 113 & 67 & 168 \\
\hline \multirow[t]{4}{*}{2} & \multirow[t]{4}{*}{ Age } & $18-29$ & 15 & 12.5 & 105 & 87.5 & 120 \\
\hline & & $30-45$ & 55 & 35 & 103 & 65 & 158 \\
\hline & & $46-59$ & 52 & 63 & 30 & 37 & 82 \\
\hline & & $>=60$ & 10 & 77 & 3 & 23 & 13 \\
\hline \multirow[t]{7}{*}{3} & \multirow{7}{*}{$\begin{array}{l}\text { Educational } \\
\text { level }\end{array}$} & Illiterate & 1 & 2 & 44 & 98 & 45 \\
\hline & & $1-4$ & 5 & 7 & 66 & 93 & 71 \\
\hline & & $5-8$ & 7 & 9 & 72 & 91 & 79 \\
\hline & & $9-12$ & 18 & 31 & 40 & 69 & 58 \\
\hline & & Diploma & 45 & 82 & 10 & 18 & 55 \\
\hline & & Degree & 41 & 84 & 8 & 16 & 49 \\
\hline & & $>=$ Masters & 15 & 94 & 1 & 6 & 16 \\
\hline \multirow[t]{4}{*}{4} & \multirow{4}{*}{$\begin{array}{l}\text { Marital } \\
\text { status }\end{array}$} & Single & 39 & 37 & 67 & 63 & 106 \\
\hline & & Marriage & 78 & 38 & 130 & 62 & 208 \\
\hline & & Divorced & 10 & 28 & 26 & 72 & 36 \\
\hline & & Widowed & 5 & 22 & 18 & 78 & 23 \\
\hline \multirow[t]{4}{*}{5} & \multirow{4}{*}{ Occupation } & Self-employed & 39 & 27 & 107 & 73 & 146 \\
\hline & & Employee & 90 & 73 & 33 & 27 & 123 \\
\hline & & House wife & 1 & 2 & 68 & 98 & 69 \\
\hline & & Others & 2 & 6 & 33 & 94 & 35 \\
\hline \multirow[t]{3}{*}{6} & \multirow{3}{*}{$\begin{array}{l}\text { Dependent } \\
\text { family size }\end{array}$} & 0 to 2 & 25 & 14 & 155 & 86 & 180 \\
\hline & & 3 to 5 & 85 & 54 & 73 & 46 & 158 \\
\hline & & 6 to 9 & 22 & 63 & 13 & 37 & 35 \\
\hline \multirow[t]{6}{*}{7} & \multirow{6}{*}{$\begin{array}{l}\text { Monthly } \\
\text { income }\end{array}$} & $<1,000$ & 7 & 7 & 93 & 93 & 100 \\
\hline & & 1,000 to 3,000 & 18 & 20 & 73 & 80 & 91 \\
\hline & & 3,000 to 5,000 & 24 & 41 & 34 & 59 & 58 \\
\hline & & $5,000-10,000$ & 36 & 58 & 26 & 42 & 62 \\
\hline & & $10,000-20,000$ & 37 & 74 & 13 & 26 & 50 \\
\hline & & $>20,000$ & 10 & 83 & 2 & 17 & 12 \\
\hline
\end{tabular}

Source: own survey (2018)

As it is depicted in the above table (table 5), item 1, gender is the first variable given in a category of male and female. With respect to the demand for life insurance, of the total number of male and female respondents, 77 and 128 number of male respondents was willing and not willing to purchase life insurance respectively, while 55 and 113 number of female respondents was willing and not willing to purchase life insurance respectively. When we compare the willingness between male and female respondents, 38 percent of male and 33 percent of female respondents were willing to purchase life insurance, while 62 percent of male and 67 percent of female respondents were not willing to purchase. Hence, even though male respondents were seems more willing to some extent to purchase life insurance than female respondents, most of the respondents from both genders was not willing and some were willing to purchase life insurance.

As it is shown in the above table (table 5), item 2, 12.5, 35, 63, and 77 percent of respondents whose age founds from 18-29, 30-45, 46-59 and greater and equal to 60 were willing to purchase life insurance respectively. On the other hand, 87.5, 65, 37 and 23 percent of respondents who were not willing to purchase life insurance were found within the age range of 18-29, 30-45, 46-59 and greater and equal to 60 respectively. This implies that most of the respondents who willing to purchase life insurance were found within the greater age range, while the low willing was found within the age range of 18 to 29. Similarly, the response for the variables of education level, dependent family size and income level shows direct relationship with the demand of life 
insurance (see table 5).

On the other hand, the response to marital status shows that $37,38,28$ and 22 percent of respondents who are single, married, divorced and widowed were willing to purchase life insurance, whereas $63,62,72$ and 78 percent of respondents who are single, married, divorced and widowed were not willing to purchase life insurance respectively. This shows that married and single respondents were to some extent more willing to purchase life insurance than these of divorced and widowed respondents. Likewise, 27, 73, 2 and 6 percent of respondents whose occupation are self employee, employee, house wife and other respectively were willing to purchase life insurance. This indicates that employee respondents were more willing to purchase life insurance which followed by self employment respondents.

\subsubsection{Communities Knowledge, Awareness, Religion and Perception Factors}

The result of the responses for these variables and their respective effect on life insurance demand is given in the below table (table 6).

Table 6: Demand of Life Insurance and Communities' Knowledge, Awareness, Religion and Perception Factors

\begin{tabular}{|c|c|c|c|c|}
\hline \multirow[t]{2}{*}{ No. } & \multirow[t]{2}{*}{ Variable } & \multirow[t]{2}{*}{ Category } & \multicolumn{2}{|c|}{ Life insurance } \\
\hline & & & Willing & Not willing \\
\hline \multirow[t]{3}{*}{1} & \multirow[t]{3}{*}{ Knowledge } & Yes & 93 & 53 \\
\hline & & No & 39 & 188 \\
\hline & & Total & 132 & 241 \\
\hline \multirow[t]{3}{*}{2} & \multirow[t]{3}{*}{ Awareness } & Agree & 118 & 45 \\
\hline & & Disagree & 14 & 196 \\
\hline & & Total & 132 & 241 \\
\hline \multirow[t]{3}{*}{3} & \multirow[t]{3}{*}{ Religion } & Agree & 67 & 118 \\
\hline & & Disagree & 65 & 123 \\
\hline & & Total & 132 & 241 \\
\hline \multirow[t]{3}{*}{4} & \multirow[t]{3}{*}{ Perception } & Agree & 25 & 219 \\
\hline & & Disagree & 107 & 22 \\
\hline & & Total & 132 & 241 \\
\hline
\end{tabular}

Source: own survey (2018)

As it is seen in the above table (table 6), item one, 93 and 53 of the respondents who said yes for the knowledge insurance were willing and not willing to purchase life insurance respectively. For respondents who said no on the other hand, 39 and 188 were willing and not willing respectively. With regard to the communities' awareness, most (196) of respondents who have low level of awareness on insurance (said disagree) are not willing to purchase life, whereas most (118) of those who have high level of awareness on insurance (said agree) are willing to purchase the policy. This implies that there is a direct relationship between knowledge and awareness of communities and demand for life. Table 6, item 3 and 4 also depicts the religion and perception of respondents and its effect on the demand for life insurance. Accordingly, most (219) of respondents who negatively perceives life insurance (said agree) are not willing to purchase life insurance, whereas most (107) of those who positively perceives life insurance (said disagree) are willing to purchase the policy. The communities' religion, on the other hand, most (118) of the respondents who are agreed with religious effect are not willing to purchase life insurance. Likewise, most (123) of the respondents who are disagreed with religious effect are again not willing to purchase life insurance. This indicates that there is a direct relationship between communities' perception towards insurance and the demand for life insurance, while there is no direct relationship between communities' religion and life insurance demand.

\subsubsection{Institutional Factors Affecting Life Insurance}

Institutional factor was also the other factor expected to affect the demand of life insurance. To evaluate the effect of institutional factors on demand of life insurance, data were collected from respondents using questionnaire, interview and focus group discussion. In the questionnaire, four specific variables including premium price, procedures in purchasing the policy, customer treatment and amount of compensation were identified that used to measure the institutional factor. Then respondents were required to state their opinion on each of these variables based on the five point likert scale. The result of these relationship is summarized in the below table (table 7). 
Table 7: Demand of Life insurance and Institutional Factors

\begin{tabular}{|c|c|c|c|c|c|c|c|}
\hline \multirow[t]{3}{*}{ No. } & \multirow[t]{3}{*}{ Variable } & \multirow[t]{3}{*}{ Category } & \multicolumn{5}{|c|}{ Demand of life Insurance } \\
\hline & & & \multicolumn{2}{|c|}{ Willing } & \multicolumn{2}{|c|}{ Not Willing } & \multirow{2}{*}{$\begin{array}{l}\text { Total } \\
\text { No. }\end{array}$} \\
\hline & & & No. & $\%$ & No. & $\%$ & \\
\hline \multirow[t]{5}{*}{1} & \multirow{5}{*}{$\begin{array}{l}\text { The premium (price) of the } \\
\text { policy is very expensive }\end{array}$} & Strongly agree & 6 & 8 & 65 & 92 & 71 \\
\hline & & Agree & 30 & 18 & 136 & 82 & 166 \\
\hline & & Neutral & 16 & 37 & 27 & 63 & 43 \\
\hline & & Disagree & 63 & 90 & 7 & 10 & 70 \\
\hline & & Strongly disagree & 17 & 74 & 6 & 26 & 23 \\
\hline \multirow[t]{5}{*}{2} & \multirow{5}{*}{$\begin{array}{l}\text { The bureaucratic procedure } \\
\text { to purchase the policy is so } \\
\text { unexciting }\end{array}$} & Strongly agree & 8 & 8 & 97 & 92 & 105 \\
\hline & & Agree & 18 & 15 & 103 & 85 & 121 \\
\hline & & Neutral & 26 & 57 & 20 & 43 & 46 \\
\hline & & Disagree & 48 & 75 & 16 & 25 & 64 \\
\hline & & Strongly disagree & 32 & 86 & 5 & 14 & 37 \\
\hline \multirow[t]{5}{*}{3} & \multirow{5}{*}{$\begin{array}{l}\text { The insurer's customer } \\
\text { treatment is not good }\end{array}$} & Strongly agree & 11 & 11 & 93 & 89 & 104 \\
\hline & & Agree & 15 & 12 & 108 & 88 & 123 \\
\hline & & Neutral & 24 & 50 & 24 & 50 & 48 \\
\hline & & Disagree & 60 & 86 & 10 & 14 & 70 \\
\hline & & Strongly disagree & 22 & 79 & 6 & 21 & 28 \\
\hline \multirow[t]{5}{*}{4} & \multirow{5}{*}{$\begin{array}{l}\text { It is very difficult to get the } \\
\text { compensation instantly }\end{array}$} & Strongly agree & 17 & 13 & 111 & 87 & 128 \\
\hline & & Agree & 18 & 14 & 109 & 86 & 127 \\
\hline & & Neutral & 21 & 72 & 8 & 28 & 29 \\
\hline & & Disagree & 55 & 85 & 10 & 15 & 65 \\
\hline & & Strongly disagree & 21 & 88 & 3 & 12 & 24 \\
\hline
\end{tabular}

Source: own survey (2018)

As indicated in table 7, first item, 8, 18,37, 90 and 74 percent of the surveyed respondents who strongly agree, agree, neutral, disagree and strongly disagree respectively with the statement of "The premium (price) of the policy is very expensive" were willing to purchase life insurance. On the other hand, 92, 82, 63, 10 and 26 percent of the surveyed respondents who strongly agree, agree, neutral, disagree and strongly disagree respectively with the statement of "The premium (price) of the policy is very expensive" were not willing to purchase life insurance. This implies that there is a direct relationship between the respondents' opinion and the respective demand for life insurance. The remaining specific variables are also held the same relationship between the dependent and independent variables (see table 7). Hence, it is possible to conclude that institutional factors are found a significant factor affecting the demand of life insurance. Furthermore, the result of the interview and focus group discussion also supports the above statements and mention additional institutional related problems including expensive the price of purchasing life insurance, claim is not attractive, lack of emphasis and promotion by insurance companies to the life insurance part.

\subsection{Binary Logistic Regression Result, Analysis and Discussion}

Beyond the descriptive analysis, econometrics model (binary logistic model) was used to identify the statistically significant variables affecting the demand for life insurance. In doing so, two commands were run: the first command shows the coefficient of ordered log-odds and the second command shows the coefficients in terms of marginal effect. Table 8 summarizes the two results (marginal effect and odds ratio) of the model. 
Table 8: Result of the Binary Logit Model for Life Insurance Demand

\begin{tabular}{|c|c|c|c|c|}
\hline & & \multicolumn{2}{|c|}{$\begin{array}{lll}\text { Number of obs } & = & 373 \\
\text { LR chi2(13) } & =452.56 \\
\text { Prob }>\text { chi2 } & = & 0.0000 \\
\text { Pseudo R2 } & = & 0.8753\end{array}$} & \\
\hline Variables & Marginal effect & $\mathbf{P}>(\mathbf{z})$ & & Odds ratio \\
\hline Gender & 1.378163 & 0.155 & & 3.967606 \\
\hline \multicolumn{5}{|l|}{ Age: } \\
\hline $30-45$ & 4.137267 & $0.002 *$ & & 62.63143 \\
\hline $46-59$ & 4.289003 & $0.006 *$ & & 72.89375 \\
\hline$>=60$ & 9.300126 & $0.001 *$ & & 109.394 \\
\hline \multicolumn{5}{|l|}{ Education: } \\
\hline $1-4$ & 5.080343 & $0.017^{* * *}$ & & 160.8292 \\
\hline $5-8$ & 6.173062 & $0.005^{*}$ & & 479.6528 \\
\hline $9-12$ & 7.124995 & $0.001 *$ & & 124.2642 \\
\hline Diploma & 6.389218 & $0.002 *$ & & 595.3909 \\
\hline Degree & 15.07347 & $0.001 *$ & & 351.8242 \\
\hline Masters \& above & 8.156972 & $0.011 * *$ & & 348.7609 \\
\hline \multicolumn{5}{|l|}{ Marital Status: } \\
\hline Married & .7015351 & 0.523 & & 2.016846 \\
\hline Divorced & 1.326322 & 0.456 & & 3.767164 \\
\hline Widowed & 3.061193 & $0.048 * *$ & & 21.35301 \\
\hline \multicolumn{5}{|l|}{ Occupation: } \\
\hline Employee & 3.728184 & $0.003 *$ & & 41.6035 \\
\hline House wife & -2.087617 & $0.086 * * *$ & & .1239823 \\
\hline Others & -4.678099 & $0.018 * *$ & & .0092967 \\
\hline \multicolumn{5}{|l|}{ Family size: } \\
\hline $3-5$ & 2.998597 & $0.011 * *$ & & 20.05738 \\
\hline $6-9$ & 3.592921 & $0.054 * * *$ & & 36.34008 \\
\hline \multicolumn{5}{|l|}{ Income level: } \\
\hline $1001-3000$ & 2.397215 & $0.044 * *$ & & 10.99252 \\
\hline $3001-5000$ & 3.383958 & $0.048 * *$ & & 29.48724 \\
\hline $5001-10000$ & 4.754342 & $0.006 *$ & & 116.0873 \\
\hline $10001-20000$ & 4.098779 & $0.010 *$ & & 60.26666 \\
\hline$>20000$ & 5.324137 & $0.017 * *$ & & 205.2311 \\
\hline Knowledge & 1.758367 & $0.059 * * *$ & & 5.802953 \\
\hline Awareness & 7.896288 & $0.000^{*}$ & & 268.7289 \\
\hline Institutional & 3.524786 & 0.008* & & 33.94651 \\
\hline Religion & 2.19422 & 0.146 & & 8.972998 \\
\hline Perception & 2.738639 & $0.021 * *$ & & 15.46593 \\
\hline /cut1 & -23.48306 & & & \\
\hline
\end{tabular}

Source: Ordinal Logistic Regression result from own survey (2018)

Note: $*, * *$ and $* * *$ indicate 1,5 and 10 percent level of significance respectively

As indicated in table 8 the numbers of observations of this study were 373 respondents and the overall pvalue is $($ Prob $>\mathbf{~ c h i 2})=0.000$ that means the p-value of the group of independent variables of this model reliably predict the dependent variable. In the model there is also a list of the variables (dependent and independent) on the first column which follows by Coefficient of marginal effect P-value and coefficient of odds ratio. The detail interpretation and discussion of the dependent variable in terms of each significant explanatory variable is given below:

Age of respondents was the first variable that found statistically significant in explaining the dependent variable (willingness to purchase life insurance) at one percent level of significance. As it is indicated in table 8 , the coefficient of marginal effect and odds ratio are given for the age group of 30 to 45, 46 to 59 and greater than or equal to 60, while the response for the age group of 18 to 29 is considered as a reference criteria. As a result, the coefficient marginal effect of the age group of 30 to 45,46 to 59 and greater than or equal to 60 were $4.1,4.3$ and 9.3 respectively; and coefficients of odds ratio for the age group of 30 to 45,46 to 59 and greater than or equal to 60 were $62.6,73$ and 109.4 respectively. This indicates that holding other factors constant, respondents in the age of 30 to 45,46 to 59 and greater than or equal to 60 increases by $4.1,4.3$ and 9.3 respectively 
compared to the respondents in the age group of 18 to 29 in purchasing life insurance. Likewise, holding other variables constant, the probability of purchasing life insurance by respondents in the age group of 30 to 45,46 to 59 and greater than or equal to 60 was 62.6, 73 and 109.4 times respectively higher than respondents in the age group of 18 to 29. Thus, it can be concluded that the probability of purchasing life insurance increases as the age of respondents increase. This finding is consistent with the studies made by Curak et at (2013); Dash (2018); Mulenga et al (2017); Mhere (2013) and Ondruska et at (2016) that reported the probability of purchasing life and insurance increases as the peoples being older.

Educational level was another socio-demographic variable which is found statistically significant at 1 percent level. As it is given in table 8 , holding other factors constant, respondents whose educational level ranges between 1 to 4,5 to 8,9 to 12, diploma, degree and masters and above increases by 5, 6, 7, 6, 15 and 8 respectively compared to the respondents whose educational level was illiterate in willingness to purchase life insurance. Likewise, holding other variables constant, the probability of purchasing life insurance by respondents whose educational level ranges between 1 to 4,5 to 8,9 to 12 , diploma, degree and masters and above increases by $161,480,124,595,352$ and 349 times respectively compared to the respondents whose educational level was illiterate in willingness to purchase life insurance. Thus, it can be concluded that the probability of purchasing life insurance increases as the educational level of respondents increase. This finding is similar with the finding of (Shahnaz \& Margaret, 2013; Curak et at, 2013; Redzuan, 2014; Mapharing et al, 2015; Ondruska et at, 2016; Akhter \& Ullah, 2017; Mulenga et al, 2017; Dash, 2018) that revealed education level have positive and significant effect on the purchase of life insurance policy.

The logistic regression results indicated in the above Table 8 reveals that occupation has a positive relation with willingness to purchase life insurance and is statistically significant at 5 percent level of significance. More specifically, the marginal effect of employees, house wife and others were $0.70,1.3$ and 3 respectively and that of self employee was held as reference variable. This implies, holding other variables constant, the probability of purchasing life insurance increases by $0.70,1.3$, and 3 for those respondents whose occupation were employee, house wife and others as compared to those of self employed. Similarly, the odd ratio shows that the probability of purchasing life insurance increases by $41.6,0.12$ and 0.01 times for those respondents whose occupation was employee, house wife and others as compared to those of self employed. Therefore, it is possible to say that employee respondents were more willing to purchase life insurance which followed by self employed. Other previous studies were also reported that peoples' occupational situation have an impact on the demand for life insurance (Curak et at, 2013; Ondruska et at, 2016; Novovic et al, 2017; Mulenga et al, 2017; Dash, 2018).

As it is revealed in Table 8, the marginal effect of respondents who have dependent family size from 3 to 5 and 6 to 9 were 3 and 3.5 respectively and those who have dependent family size from 0 to 2 was held as reference variable. This implies, holding other variables constant, the probability of purchasing life insurance increases by 3 and 3.5 for those respondents who have dependent family size from 3 to 5 and 6 to 9 as compared to those who have dependent family size from 0 to 2 . Similarly, the odd ratio shows that the probability of purchasing life insurance increases by 20 , and 36.3 times for those respondents who have dependent family size from 3 to 5 and 6 to 9 as compared to those who have dependent family size from 0 to 2 . From this it is possible to say that the willingness to purchase life insurance increases as the number of dependent family size goes large. Unlike to the findings of (Curak et at, 2013; Dash, 2018) that found insignificant effect of family size on the purchase of life insurance, this result is consistent with the result of (Mhere, 2013; Shahnaz \& Margaret, 2013; Redzuan, 2014; Mapharing et al, 2015; Simon, 2016 Akhter \& Ullah, 2017) that reported dependency ratio is positively related to the demand for life insurance.

With regard to the income level table 8 shows that holding other factors constant, respondents whose income level ranges between Birr 1001 to 3000,3001 to 5000,5001 to 10000,10001 to 20000 and greater than 20000 increases by $2.4,3.4,4.7,4$ and 5.3 respectively compared to the respondents whose income level was less than 1000 in willingness to purchase life insurance. Likewise, holding other variables constant, the probability of purchasing life insurance by respondents whose income level range between Birr 1001 to 3000 , 3001 to 5000,5001 to 10000,10001 to 20000 and greater than 20000 increases by $11,29.5,116,60.3$ and 205.2 respectively compared to the respondents whose income level was less than Birr 1000 in willingness to purchase life insurance. Thus, it can be concluded that the probability of purchasing life insurance increases as the income level of respondents increase because respondents with higher income level showed the highest percentage of willingness to purchase life insurance as compared to those of poor. This result is consistent with the finding of previous researchers (Beck and Webb, 2003; Nesterova, 2008; Li et.al, 2007; Çelik and Kayali, 2009; Redzuan, 2011; Loke and Goh, 2012; Aderaw, 2013; Idham et al, 2014; Simon, 2016; Akhter and Ullah, 2017) that reported income level is a positive and significant variable affecting the demand for life insurance.

Other things remain constant, the probability of purchasing life insurance increases by 1.8 for those who said yes for the knowledge of insurance as compared to those who those who said no for the knowledge of insurance. Likewise, the odd ratio of 5.8 indicates that the probability of purchasing life insurance increases by 5.8 times for those who said yes for the knowledge of insurance as compared to those who said no for the 
knowledge of insurance. With regard to the awareness of respondents on insurance, table 4.10 revealed that it positively affects the willingness to purchase life insurance at 10 percent level of significance. Numerically, the probability of purchasing life insurance increases by 268.7 times for those who have awareness on insurance as compared to those who didn't have awareness on insurance holding other variables constant. Hence, it is possible to conclude that knowledge and awareness on insurance positively affects the willingness to purchase life insurance. Similar finding were found by Kansra and Pathania (2012) that indicated that the main barrier in the success of health insurance in the study area is peoples' awareness on insurance in general and on life and /or health insurance in particular.

With respect to the institutional variables, other things remain constant, the probability of purchasing life insurance increases by 3.5 for those who agreed with the institutional factors as compared to those who didn't agreed. In other words, the probability of purchasing life insurance increases by 34 times for those who agreed with the institutional factors as compared to those who didn't agree. Other previous researchers (Beck \& Webb, 2003; Idham et al, 2014; Simon, 2016; Dash, 2018) were also reported that institutional factors such as price, complexity, customer handling and other variables were significantly affecting the demand for life insurance. To sum up, based on the above inferential analysis age, educational level, occupation, income level, number of dependent family size, knowledge, awareness, institutional factors and perception were found statistically significant factors that determine the willingness to purchase life insurance, whereas gender, marital status and religion were found statistically insignificant factors in determining willingness to purchase life insurance.

\section{Conclusion}

The demand for life insurance which is measured by the respondents' willingness to purchase life insurance was low with different reasons such as less capita, unnecessarily, having Idir and so on. The general know how of the surveyed respondents about insurance was low with insufficient awareness level of the surveyed respondents about the necessity and using of life insurance. In the study it is possible to conclude that respondents perceived as life insurance is for rich peoples; idir substitutes life insurance policy; life insurance contradicts with religion and culture; it is expensive; it could not cover psychological effect; and it's coverage is not financially sufficient. The probability of willingness to purchasing life insurance increases as the age, educational level, family size and income level of respondents increase. Besides, respondents' occupation, knowledge, awareness, religion and perception were statistically significant variables affecting the demand for life insurance. The result of the study also revealed that there is a statistically significant relationship between the institutional factors and respondents' willingness to purchase life insurance.

\section{Recommendation}

Insurance companies and policy makers should provide various life policies that can suit the clients having different socio-demographic and economic conditions. That means there should be supplies of various life insurance coverages in different forms that satisfy clients at different age group, having different family size, income level and other situations. The concerned government bodies, insurance companies and academicians should open academic centers, mass medias and other means in which discussions, conferences, workshops and trainings can be provided that help to develop the communities' knowledge, awareness and perception about insurance in general as well as life insurance in particular. Besides, insurance companies should offer different encouragement methods like bonus that may attract communities to purchase life insurance coverage which there by improve their perception on the policies.

\section{Reference}

Aderaw G. (2013). Determinants of Life Insurance in Ethiopia: International Journal of Research in Commerce \& Management. Vol. 4, Issue No. 02

Akhter, W. and Khan, S. (2017). Determinants of Takāful and conventional insurance demand: A regional analysis. Cogent Economics \& Finance, 5:1291150.

Berekson, L. (1972). Birth Order, Anxiety, Affiliation and the Purchase of Life Insurance. Journal of Risk and Insurance, Volume 39, pp. 93-108.

Curak, M., Dzaja, I., and Pepur, S. (2013). The Effect of Social and Demographic Factors on Life Insurance Demand in Croatia. nternational Journal of Business and Social Science Vol. 4 No. 9; August 2013.

Dash, G. (2018). Determinants Of Life Insurance Demand: Evidences From India. Asia Pacific Journal of Advanced Business and Social Studies: ISSN: 2205-6033, Vol. 4/2.

Fischer, S. (1973). A life cycle model of life insurance purchases. International Economic review. 14 (1).

Fortune, P. (1973). A Theory of Optimal Life Insurance: Development and Test, Journal of Finance, Volume 27. Francois, o. (1994). Life Insurance in Developing Countries: A cross-country analysis.

George E.Rejda (2003). Principles of risk management and insurance.

Hailu, Z. (2007). Insurance in Ethiopia: Historical Development, Present Status and Future Challenges, Addis 
Ababa: Master Printing Press.

Hammond, J. Houston, D. \&Melander, E. R. (1967). Household Life Insurance Premium Expenditures: An Empirical Approach, Journal of Risk and Insurance, 34/3.

Headen, R. and Lee, J. (1974). Life Insurance Demand and Household Portfolio Behavior. Journal of Risk and Insurance, Volume 41.

Idham, M., Hawa, S., Ghazali, R., Paramasivam, S., and John, G. (2014). An Overview of Demand for Life Insurance in Malaysia; International Journal of Humanities and Social Science Vol. 4 No. 4.

Karni, E. and Zilcha I. (1985). Uncertain Lifetime, Risk Aversion and Life Insurance,” Scandinavian Actuarial Journal.

Lenten, L. J. A., \& Rulli, D. N. (2006). A Time-Series Analysis of the Demand for Life Insurance Companies in Australia: Australian Journal of Management, 31(1).

Lewis, E. (1989). Dependents and the Demand for Life Insurance, American Economic Review, 79/3.

Luciano, E. Outreville, F. and Rossi, M. (2015). Life insurance demand: evidence from Italian households; a micro-economic view and gender issue. Netspar Discussion Paper, University of Turin, Italy.

Madura, J. (2010). Financial markets and institutions,9th edition

Mapharing, M., Otuteye, E., and Radikok, I. (2015). Determinants of Demand for Life Insurance: The Case of Canada. Journal of Comparative International Management; Vol. 18, No. 2, 1-22

Marijana, C., Ivana, D., and Sandra, P. (2013). The Effect of Social and Demographic Factors on Life Insurance Demand in Croatia. International Journal of Business and Social Science, Vol. 4 No. 9; Republic of Croatia.

Mezgebe M. (2015). The Ethiopian Insurance Industry and the Reinsurance Business' Legal Environment: Ethiopian Development Research Institute, Addis Ababa, Ethiopia

Mhere, F. (2013). Health insurance determinant in Zimbabwe: Case of Gweru Urban. Journal of Applied Business and Economics; vol. 14(2)

Mossin, J. (1968). Aspects of Rational Insurance Purchasing,\| Journal of Political Economy, 79.

Mulenga, J., Bwalya, B., and Yordanos, G. (2017). Demographic and socio-economic determinants of women's health insurance coverage in Zambia. Epidemiology Biostatistics and Public Health - 2017, Volume 14, Number 1

National Bank of Ethiopia (2015). Birritu magazine, issue number. 111.

Novovic, M., Cerovic, J., Lipovina, M. and Lalevic, A. (2017). Impact of economic factors on life insurance development in Western Balkan Countries. Zb. rad. Ekon. fak. Rij. • 2017 • vol. 35 • no. 2 • 331-352.

Office of the Commissioner of Insurance (2013). Principles and practice of insurance examination, fifth edition

Ondruska, T., Pastorakova, E., and Brokesova, Z. (2016). Personal, Demographic and Economic Determinants of the Life Insurance Consumption. Sixth Asia-Pacific Conference on Global Business, Economics, Finance and Social Sciences (AP16Thai Conference) ISBN: 978-1-943579-10-5

Outreville, F.J. (1996) Life Insurance Markets in Developing Countrie, Journal of Risk and Insurance; 63:263278.

Pissarides, C. (1980). The Wealth-Age Relation with Life Insurance. Economica , 47.

Redzuan, H. (2014). Analysis of the Demand for Life Insurance and Family Takaful. Proceedings of the Australian Academy of Business and Social Sciences Conference 2014 (in partnership with The Journal of Developing Areas) ISBN 978-0-9925622-0-5, University Kebangsan Malaysia.

Roman G. (2011), Determinants of life insurance demand in Ethiopia",college of business and Economics, department of Economics Addis Ababa University.

Savvides, S. (2006). Inquiry into the Macroeconomic and Household Motives to Demand Life Insurance: Review and Empirical Evidence from Cyprus. Journal of Business and Society, 19, 37-79.

Shahnaz, N. and Margaret, S. (2013). The Determinants of Life Insurance Demand: A Focus on Saving Motives and Financial Literacy. Asian Social Science; Vol. 9, No. 5; 2013 ISSN 1911-2017 E-ISSN 1911-2025; Published by Canadian Center of Science and Education

Simon, N. (2016). Macro Level Determinants of Life Insurance Purchasing Demand in Ethiopia. International Journal of Research in Economics and Social Sciences (IJRESS); ISSN: 2249-7382, Vol. 6 Issue 12.

Taiwo Akinlo and Olumuyiwa Tolulope Apanisile Vol.5 No.2 (2014) :"Relationship between Insurance and Economic Growth in Sub-Saharan African: A Panel Data Analysis", Department of Economics, Adeyemi College of Education, Ondo, and Obafemi Awolowo University, Ile-Ife, Nigeria sited.

Thorsten, B. and Ian, W. (2002). Economic, Demographic, and Institutional Determinants of Life Insurance Consumption across Countries. World Bank and International Insurance Foundation

Yaari, M. (1965). Uncertain Lifetime, Life Insurance, and the Theory of the Consumer, Review of Economic Studies.

Yilma, A. (2014). Determinants of life insurance demand in Ethiopia. A thesis work in the department of Accounting and finance, Addis Ababa University, Addis Ababa. 